\title{
Invisible barriers: Differential sanitary regulations constrain vulture movements across country borders
}

\author{
Eneko Arrondo ${ }^{\mathrm{a}, *}$, Marcos Moleón $^{\mathrm{a}, \mathrm{b}}$, Ainara Cortés-Avizanda ${ }^{\mathrm{a}, \mathrm{g}}$, José Jiménez ${ }^{\mathrm{c}}$, Pedro Beja ${ }^{\mathrm{d}, \mathrm{e}}$, \\ José A. Sánchez-Zapata ${ }^{\mathrm{f}}$, José A. Donázar ${ }^{\mathrm{a}}$ \\ a Department of Conservation Biology, Doñana Biological Station-CSIC, 26, 41092 Sevilla, Spain \\ ${ }^{\mathrm{b}}$ Department of Zoology, University of Granada, 18071 Granada, Spain \\ ${ }^{\mathrm{c}}$ Institute for Game and Wildlife Research-CSIC, 13005 Ciudad Real, Spain \\ d CIBIO/InBio-UP, Centro de Investigação em Biodiversidade e Recursos Genéticos, Universidade do Porto, 4485-661 Vairão, Portugal \\ e 2CEABN/InBio, Centro de Ecologia Aplicada "Professor Baeta Neves", Instituto Superior de Agronomia, Universidade de Lisboa, Tapada da Ajuda, 1349-017 Lisboa, \\ Portugal \\ ${ }^{\mathrm{f}}$ Department of Applied Biology, University Miguel Hernández, 03202 Elche, Spain \\ ${ }^{g}$ Animal Ecology and Demography Group, IMEDEA (CSIC-UIB), Miguel Marques 21, 07190 Esporles, Spain
}

\section{A R T I C L E I N F O}

\section{Keywords:}

Aegypius monachus

Ecological barriers

EU sanitary policies

Extensive livestock

Gyps fulvus

Iberian Peninsula

Political boundaries

Portugal

Scavengers

Spain

\begin{abstract}
A B S T R A C T
Political boundaries may represent ecological barriers due to differences in wildlife management policies. In the European Union, it might be expected that these differences should be highly diluted, because all countries have to comply with common directives issued by the European Commission. However, the subsidiarity principle may lead to the uneven uptake of European Union regulations, which can impact on biodiversity conservation due to unequal legislation in neighboring countries, particularly in the case of highly mobile organisms. Here we address this issue, by analyzing how EU regulations issued in response to the Bovine Spongiform Encephalopathy (BSE) crisis differentially affected vulture conservation in Portugal and Spain. Taking advantage of the intensive GPS-tracking of 60 griffon (Gyps fulvus) and 11 cinereous vultures (Aegypius monachus) from Spain, we found that the Spanish-Portuguese border acts as a quasi-impermeable barrier. In fact, there was an abrupt decline in the number of vulture locations across the Spanish-Portuguese border, with modelling showing that this was unlikely to be related to differences in land cover or topography. Instead, the pattern found was likely due to differences in trophic resource availability, namely carcasses from extensive livestock husbandry, resulting from the differential application of European sanitary legislation regarding the mandatory removal of dead livestock from the field. Overall, our results should be seen as a warning signal to policy makers and conservation managers, highlighting the need for a stronger integration of sanitary and environmental policies at the European level.
\end{abstract}

\section{Introduction}

Human frontiers are based on political and socio-economic criteria, and seldom have an ecological foundation (López-Hoffman et al., 2010; Dallimer and Strange, 2015). As a consequence, wildlife, especially highly mobile organisms, may encounter different degrees of human impact, disparate conservation regulations, and contrasting environmental policies within otherwise homogeneous ecological regions (Bolger et al., 2008; Perz et al., 2013; Lambertucci et al., 2014; Gervasi et al., 2015). Addressing these differences has been the goal of a range of conservation initiatives, such as international conventions and regulations (e.g., the Bern Convention and the European Habitats and
Species Directive). However, undesirable transboundary effects on biodiversity are still common in natural systems and deserve more scientific and management attention.

Transboundary conservation challenges are likely to occur when different countries implement different environmental policies (Gervasi et al., 2015), or when hard borders are planned or implemented, such as the infamous US-Mexico border wall (Cohn, 2007; Lasky et al., 2011). To solve these problems, a number of initiatives have been developed, often based on the creation of transboundary protected areas (Sandwith et al., 2001), or through ambitious projects involving transboundary natural resource management initiatives with wider benefits for conservation and sustainable development (e.g. Wolmer, 2003). It is

\footnotetext{
* Corresponding author at: Doñana Biological Station-CSIC, Avda. Américo Vespucio, 26, 41092 Sevilla, Spain.

E-mail address: eneko@ebd.csic.es (E. Arrondo).
} 
possible; however, that even simple coordination of environmental policies in neighboring countries might achieve significant conservation benefits, thereby avoiding abrupt changes in regulations and practices across borders (Gervasi et al., 2015). In Europe, it might be expected that a high degree of policy integration across countries would achieve such biodiversity conservation benefits, as there are general directives emanating from the European Commission that regulate key issues such agriculture, water management, environmental pollution, and biodiversity conservation itself, among other aspects (Hodge et al., 2015). However, the subsidiarity principle adopted by the European Commission implies that countries, and even regions within countries, have a wide flexibility on how the directives are applied in practice, depending on local policy, socioeconomic and ecological contexts (Kukkala et al., 2016). This may have significant implications for conservation, particularly for migratory or otherwise wide-ranging species, though to the best of our knowledge this idea has never been tested explicitly. However, addressing this issue would be important, because it may help guiding efforts for a better integration across Europe of policies that impact on biodiversity conservation (Sánchez-Fernández et al., 2017).

The bovine spongiform encephalopathy (BSE) crisis provides a unique case study to examine the conservation consequences of the differential uptake across countries of regulations emanating from the European Commission regulations. In 2001, after the BSE crisis, the EU prohibited the abandonment of livestock carcasses in the field (EC 1774/2002; Donázar et al., 2009). The subsequent change in carrion availability resulted in disturbances at different ecological levels, including changes in scavenger communities, disruption of intra-guild relationships, and an increment in $\mathrm{CO}_{2}$ emissions associated with the transport of carcasses to transformation and incineration plants (Morales-Reyes et al., 2015; Cortés-Avizanda et al., 2016). Fortunately, the consensus among scientists and conservation managers led to improved EU legislations (CE 322/2003, CE 830/2005 CE 142/2011; Margalida et al., 2012), which partially reconciled sanitary requirements with biodiversity conservation concerns (Morales-Reyes et al., 2017). Nevertheless, the new legal framework did not establish mandatory guidelines for member states, which are allowed to develop their own regulations concerning livestock carcass disposal. This has resulted in a paradoxical situation where neighboring countries in a continuous ecological region may apply different criteria, as occurs in the Iberian Peninsula. In Spain, home to c. $95 \%$ of European vultures (Margalida et al., 2010), the CE 830/2005 made the requirements to dispose carcasses for feeding vultures at authorized feeding points more flexible, and the prohibition on carcass disposal was unofficially lifted. More recently, new European regulations led to the designation of a network of "Protection areas for the feeding of necrophagous species of European interest" (Royal Decree 1632/2011; Morales-Reyes et al., 2017) as an attempt to mitigate food shortage for scavengers and associated environmental costs (Margalida et al., 2010; Morales-Reyes et al., 2015). In contrast, the Portuguese governmental authorities still require livestock breeders to remove dead animals from the field (Decreto-lei $38 / 2012$ ), with the exception of a few scavenger feeding stations (all located close to the Spanish border) that may be supplied with livestock carcasses under very restrictive licensing conditions (Monteiro et al., 2009).

Here, our main objective was to show that differences in the uptake of EU regulations across countries can impact on biodiversity, using vulture conservation in Portugal and Spain as a case study. Specifically, we wanted to determine how foraging individuals of the two most common Iberian vulture species respond to the asymmetric implementation of EU sanitary regulations, while controlling for potentially confounding factors associated with differences in topography, land cover and livestock density. We took advantage of three GPStracking projects, involving two populations of griffon vulture (Gyps fulvus) and one of cinereous vulture (Aegypius monachus), which provided detailed information on individuals space use in $50-\mathrm{km}$ buffers on each side of the border. Our main prediction is that vultures will avoid the Portuguese territory, where livestock removal from the field has been more rigorous and is still mandatory, thereby resulting in lower food availability.

\section{Methods}

\subsection{Study area}

We focused our analyses on vulture foraging around the SpanishPortuguese border, which is largely defined by river valleys and is not associated with any abrupt or systematic change in terms of climate, topography or land cover (Clark Labs, 2000; AEMET I., 2011; CEC, 2012). We defined our study area in two steps. First, we established the lateral limits by generating a grid of $10 \times 10 \mathrm{~km}$ cells over a $50 \mathrm{~km}$ buffer on both sides of the border. All cells completely or partially included in the $50 \mathrm{~km}$ buffer were considered. Second, we selected $90 \%$ of locations inside the buffer strips to exclude accidental non informative locations. This established the northern limit at latitudes $40^{\circ} 30^{\prime} 51^{\prime \prime}$ north and the southern limit at $37^{\circ} 43^{\prime} 06^{\prime \prime}$ north. The result is a study area composed by $44510 \times 10 \mathrm{~km}$ cells (Fig. A1), being $22,541.55 \mathrm{~km}^{2}(50.7 \%$ of the whole study area) in Portugal and $21,958.45 \mathrm{~km}^{2}$ in Spain. Most of the study area is covered by pastures and crops with scattered native trees (mainly Quercus ilex and Q. suber), a savanna-like landscape called "dehesa" in Spain and "montado" in Portugal. This habitat has been historically managed for livestock (mainly sheep and pig) and agricultural (mainly cereals) purposes (Acácio et al., 2016; Garrido et al., 2017). This combination of human traditional uses with natural vegetation creates a semi-open habitat, which is very favorable for a range of wildlife species (Moreno et al., 2016), particularly for large scavengers (Carrete and Donázar, 2005). In addition, the study area includes vast expanses of shrubland dominated by Cistus ladanifer and Cytisus scoparius, and commercial plantations of Eucalyptus spp., Pinus pinaster and P. pinea. Extensive livestock husbandry is widespread on both sides of the border, with animals grazing in dehesa/montado woodlands or in more open pastures (Sales-Baptista et al., 2016). There are also wild ungulates on both sides of the border, mainly red deer Cervus elaphus and wild boar Sus scrofa (Apollonio et al., 2010), which may provide an additional source of carrion to vultures, but there is no information on spatial variation in their abundance.

\subsection{Vulture GPS tracking}

Griffon and cinereous vultures, which are considered as Least Concern and Near Threatened respectively (BirdLife International, 2016, 2017), are the main obligate scavenger species of Europe. Iberian Peninsula hold $90 \%$ of European population of both species being much abundant griffon vulture (Margalida et al., 2010) which population is estimated in 24,609 breeding pairs (del Moral, 2009) in Spain and 500-1000 breeding pairs in Portugal (ICNB, 2017). Breeding colonies are widely distributed along the Iberian Peninsula (MAPAMA, 2017; Fig. A2). On the other hand, cinereous vulture colonies are mostly distributed in the western-central sector of the peninsula (Fig. A2) and the population estimate is 1845 breeding pairs in Spain (de la Puente et al., 2007) and 11 breeding pairs in Portugal (ICNB, 2017).

We captured and tagged 30 adult griffon vultures in the Guadalquivir Valley, southern Spain (Fig. A2). These birds were monitored between December 2014 and December 2016 (see Table A1). Another 30 adult griffon vultures were tagged in the Ebro Valley, northern Spain (Fig. A2), and monitored between December 2015 and December 2016 (see Table A1). All birds were captured by cannon nets at baits and equipped with $90 \mathrm{~g}$ GPS/GPRS-GSM devices from e-obs digital telemetry (http://www.e-obs.de). Cinereous vultures, 9 fledglings captured at the nest and 2 sub adults trapped by folding net (García-Matarranz, 2011), were tagged in Cabañeros National Park, 
central Spain (Fig. A2). All of them were tracked between July 2006 and March 2009 (see Table A1). Cinereous vulture individuals were equipped with $70 \mathrm{~g}$, Solar Argos/GPS PTT-100 s from Microwave Telemetry Inc. (http://www.microwavetelemetry.com). GPS devices of both species were equipped following the procedures described in Kenward (2000). Details of the birds studied and individual tracking process are provided in supplementary material, Tables A1 and A2.

\subsection{Environmental variables}

Vulture distributions were modeled in relation to five explanatory variables: i) "country" (i.e., Portugal versus Spain); ii) "livestock", an estimation of the alive domestic species density. This is a common proxy of the potential carrion biomass availability (Margalida et al., 2011; Morales-Reyes et al., 2015) which we calculated as the number of heads of sheep, pigs and goats divided by the surface area of each local municipality. We excluded cattle because they cannot be abandoned in the field either in Portugal or in Spain; iii) dominant "habitat", according to the main CORINE land cover levels in each cell (CEC, 2012); iv) "roughness" or landscape relief, estimated as the mean Topographic Position Index (TPI; Dilts, 2015) of each cell, and v) "distance" to the border. This variable was estimated by rasterizing the study area and calculating for each cell the mean distance (in $\mathrm{km}$ ) of each pixel to the border.

In the case of the griffon vulture, we did not include a variable coding the "population" because the proportion of flying locations within each country did not differ between individuals belonging to the Guadalquivir and Ebro populations $\left(\chi^{2}: 3.372\right.$; df: $\left.1 ; \mathrm{p}: 0.066\right)$. We used official sources to obtain the number of livestock heads (MAGRAMA: http://www.magrama.gob.es/; INE: https://www.ign.es/) and the area of each municipality (DGT: http://www.dgterritorio.pt/; IGN: https:// www.ign.es/). CORINE categories considered were: agroforestry, sclerophyllous vegetation, broad-leaved forestry, olive grove, grassland, permanently irrigated lands, non-irrigated land, and others, which grouped those habitats that were dominant in $<10$ cells. Distance to the border and livestock variables were rescaled by subtracting the mean of the variable to the value of each cell and dividing by the standard deviation.

\subsection{Data analysis}

We modeled the density of griffon and cinereous vulture locations per squared km using Generalized Linear Models (GLM), with a negative binomial error distribution and logit link function. We fitted separate models for each vulture species, including in each case country, livestock, roughness, habitat and distance, as explanatory variables. We considered as response variable the density of foraging locations (number of foraging locations in each $10 \times 10 \mathrm{~km}$ cell; Fig. A1). To define foraging locations we adapted the methodology described by Silva et al. (2017). We carried out a visual inspection of the ground speed data distribution and established a conservative threshold of $5 \mathrm{~m} / \mathrm{s}$ (see Fig. A3). Locations under this ground speed were considered as non-foraging activity and we excluded from the analyses. We established this high threshold to be sure that we were excluding all not foraging activities such as perching, walk or preening.

To discard possible individual effects (e.g. sex, breeding status or period tracked) we performed an alternative set of models. In this case, we modeled the occurrence of griffon and cinereous vultures using Generalized Linear Mixed Models (GLMMs), with binomial error distribution and logit link function. We performed different model for griffon and cinereous vulture, including in both cases the individual identity as random factor and country, livestock, roughness, habitat and distance as explanatory variables. The response variable was, in both cases, presences/pseudo-absences of vulture locations. Vulture locations inside the study area were used as presences and pseudo-absences were randomly distributed within the study area, excluding a buffer of
$40 \mathrm{~m}$-radius around each presence location. We generated the same number of pseudo-absences than presence locations (Table A3). Previously, we explored spatial autocorrelation effects performing Spatial Generalized Linear Mixed Models and testing exponential, spherical and power structures (Dormann et al., 2007) in SAS (SAS Institute, 2009). Results of these explorative models did not include any of the structure tested. This allowed us to discard possible spatial autocorrelation effects also in the GLM due to density approaches are more resilient to this kind of bias than presence/absence models (Aarts et al., 2012).

For model selection, in both cases (GLM and GLMM), we first built a saturated model with all the explanatory variables and those interactions that were ecologically sound. We then performed a backward stepwise procedure using the drop1 function, which is based on the Akaike's information criterion (AIC), to remove non-significant variables $(P>0.05)$. Spatial analyses were done using ArcGis 10.2.1 (ESRI, 2016), and models were developed in R (R Core Team, 2016).

\section{Results}

We obtained a total of 24,302 and 366 locations of griffon and cinereous vultures, respectively inside the study area (see Methods). Thirteen griffon vultures, six from the Guadalquivir Valley $(20.0 \%$ of the total tagged in this population) and seven from Ebro Valley (23.3\% of the total tagged in this population), as well as nine cinereous vultures ( $81.8 \%$ of the total tagged), visited the study area. Only six griffon vultures (four from Guadalquivir and two from Ebro representing 4.4\% of the total tagged) and seven cinereous vultures (28.4\% of the total tagged) visited the Portuguese side of the study area. A visual inspection of the vulture locations revealed an evident contrasting use of each country (Figs. 1 and A1), with the Spanish-Portuguese border appearing as a quasi-impermeable barrier. The mean distance to the border of griffon vulture locations (including those out of the study area) inside Portugal was $9 \mathrm{~km}$ with a maximum distance of $87 \mathrm{~km}$. In the case of the cinereous vulture, the mean distance to the border was $12 \mathrm{~km}$ and the farthest location from the border was at $94 \mathrm{~km}$.

GLM and alternative GLMM (Tables 1 and A3) show analogue results, which are in accordance with previous studies which suggest that both modelling approaches (locations density and presence/pseudoabsences) tend to provide very similar outputs (see Aarts et al., 2012). In view of these similarities, we decided to maintain the GLM as main approach because it showed a more accurate influence of the habitat variable (see Tables 1 and A3).

Models selected (Table 1 and A4) for either griffon or cinereous vultures were very similar (Table 1 ). These models indicated that the density of foraging locations of both species was higher in Spain than in Portugal. There was also a significant interaction between country and distance to the border, indicating that within Portugal the density of foraging locations declined steadily with distance to the border, while within Spain it remained largely constant at higher levels (Fig. A4). Additionally, habitat was important to explain the density of foraging locations of both species, with higher values found in agroforestry, sclerophyllous vegetation, grassland and broad-leaved forestry than in more humanized habitats. The model for griffon vultures also included a positive effect of livestock density, while this variable was not retained in the model selected for cinereous vultures.

\section{Discussion}

Our results clearly confirm the idea that there is a strong difference in the occurrence patterns of griffon and cinereous vultures between Portugal and Spain. We found that griffon and cinereous vultures from Spain rarely fly beyond the Portuguese border, especially as the distance from Spain increases (see Figs. 1, A1 and A4), even after controlling for the potentially confounding effects of topography, land cover and livestock density. In addition, the low number of non-flying 

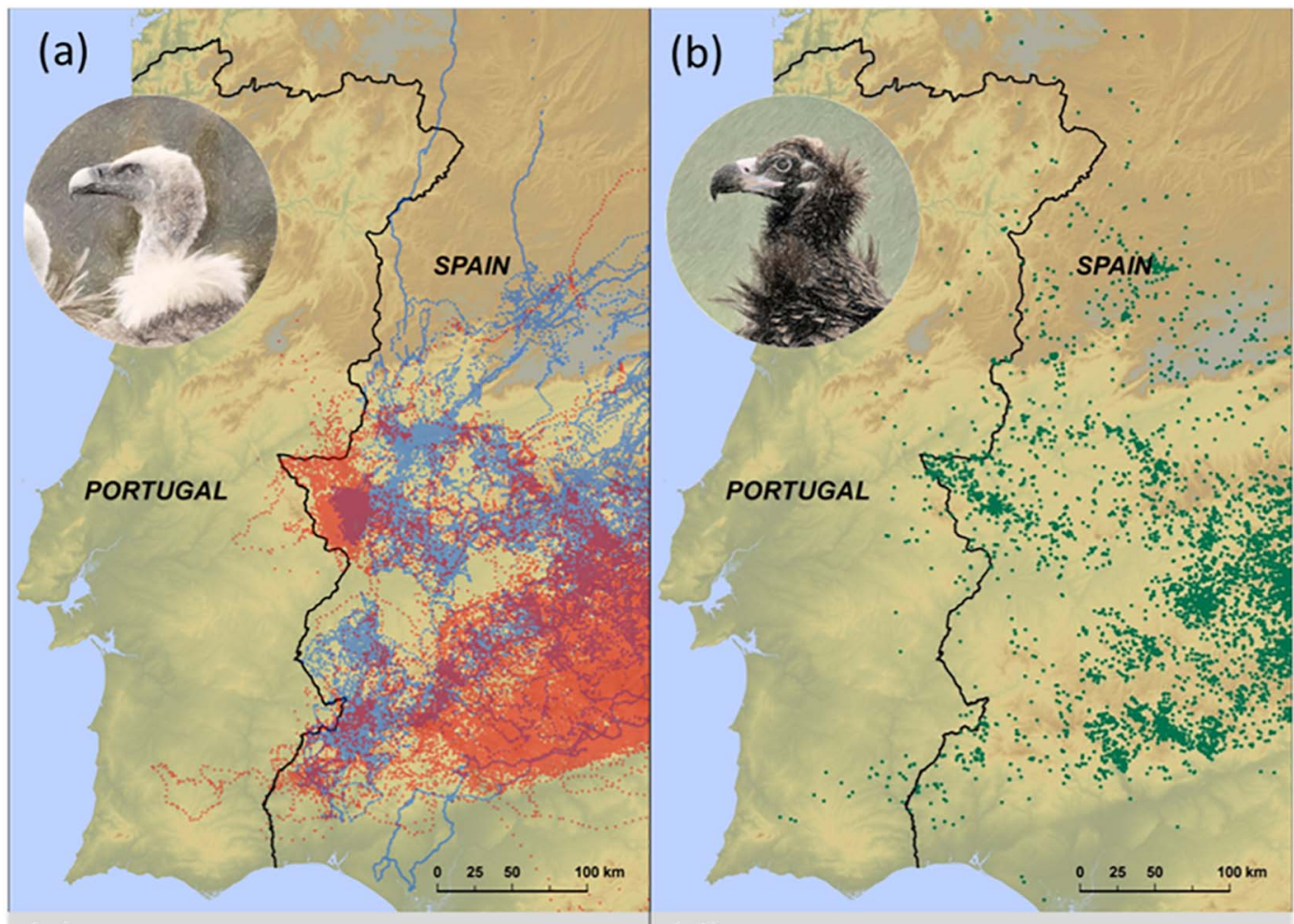

(c)

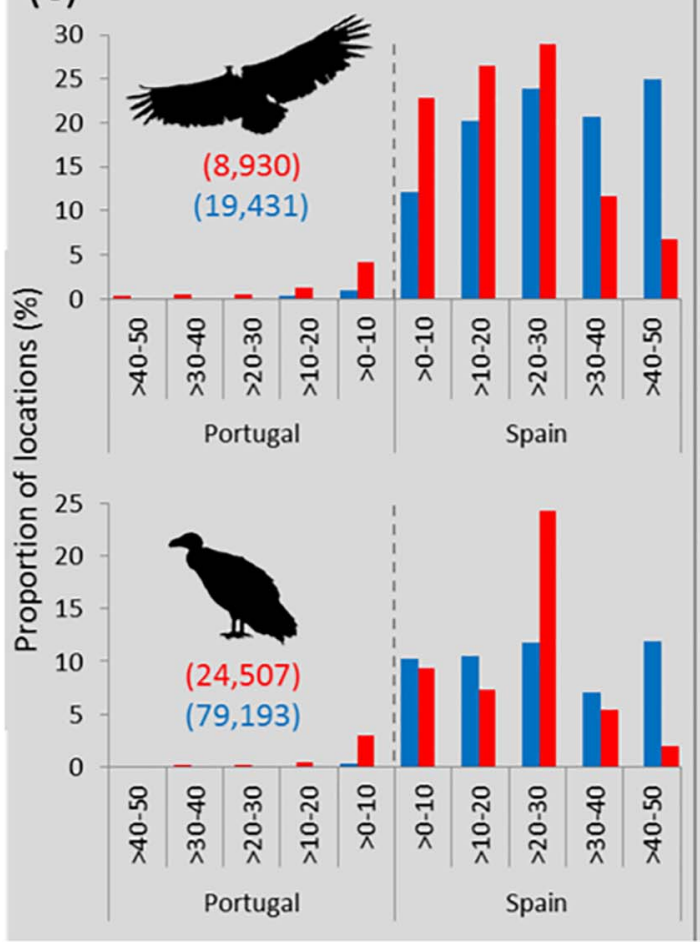

(d)

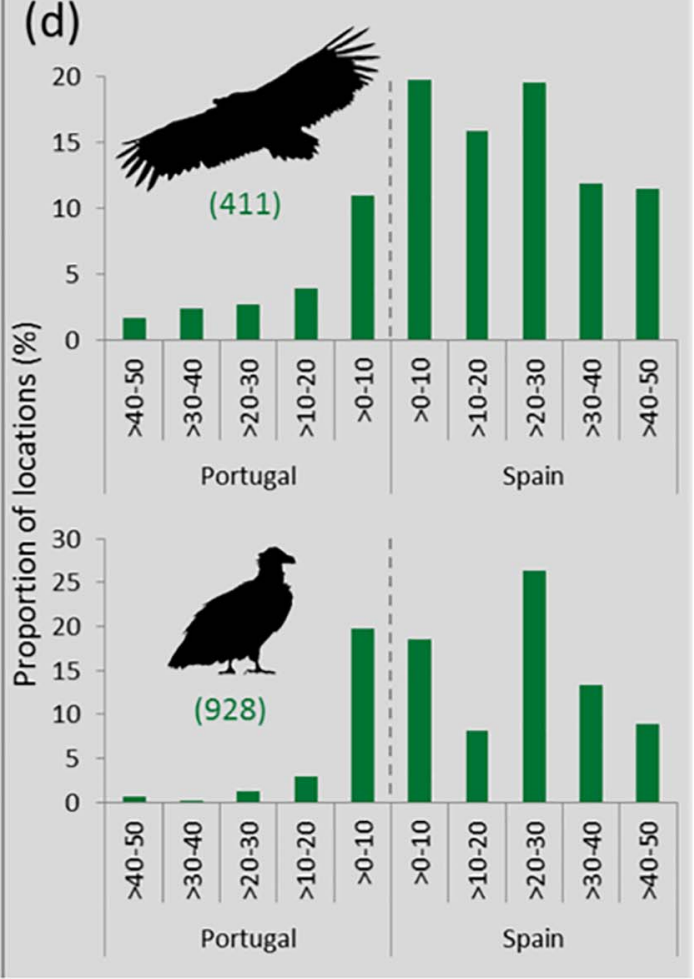

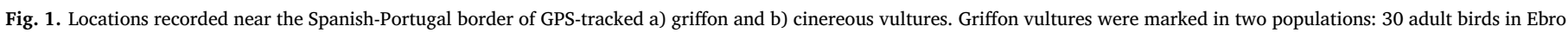

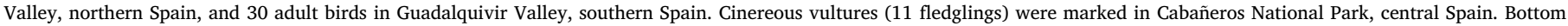

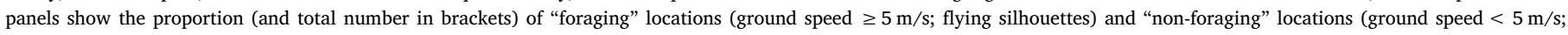

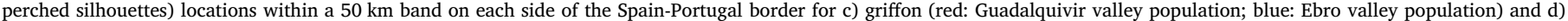
cinereous vultures. (For interpretation of the references to colour in this figure legend, the reader is referred to the web version of this article.)

locations (i.e., speed ground $<5 \mathrm{~m} / \mathrm{s}$; see Fig.1) of both species in Portugal suggests that Spanish vultures rarely feed on that side of the border. This strong border effect seems to be the consequence of the unequal application of European legislation regarding livestock carcass disposal in the Iberian countries. In Portugal, the active removal of carcasses from extensive livestock husbandry systems is probably largely emptying the fields of a key vulture food resource, to the point that the Portuguese side of the Spain-Portugal frontier is avoided by the main European obligate scavengers. Overall, therefore, these results are in line with the idea that the differential uptake of EU regulations across 
Table 1

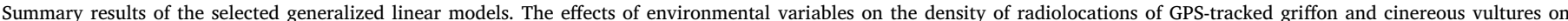

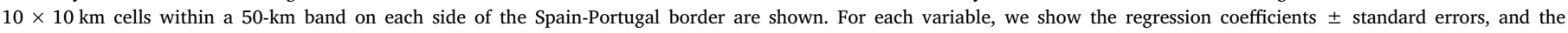
corresponding $Z$-values.

\begin{tabular}{|c|c|c|c|c|}
\hline Response variable & Explanatory variable & Level & Estimate $\pm \mathrm{SE}$ & Z-value \\
\hline \multirow[t]{15}{*}{ Griffon vulture locations density } & \multirow[t]{2}{*}{ Country } & Portugal(Intercept) & $-3.04 \pm 0.54$ & -5.62 \\
\hline & & Spain & $3.72 \pm 0.19$ & 19.18 \\
\hline & Livestock & & $0.76 \pm 0.12$ & 6.43 \\
\hline & Roughness & & $0.24 \pm 0.08$ & 2.86 \\
\hline & \multirow[t]{9}{*}{ Habitat } & Non-irrigated arable land (Intercept) & $-3.04 \pm 0.54$ & -5.62 \\
\hline & & Permanently irrigated land & $-0.50 \pm 0.42$ & -1.18 \\
\hline & & Olive groves & $-1.43 \pm 0.52$ & -2.76 \\
\hline & & Agro-forestry areas & $0.89 \pm 0.26$ & 3.40 \\
\hline & & Broad-leaved forest & $0.20 \pm 0.33$ & 0.59 \\
\hline & & Natural grasslands & $0.71 \pm 0.35$ & 1.98 \\
\hline & & Sclerophyllous vegetation & $0.36 \pm 0.41$ & 0.89 \\
\hline & & Transitional woodland-shrub & $0.47 \pm 0.30$ & 1.58 \\
\hline & & Others & $-0.41 \pm 0.39$ & -1.05 \\
\hline & Distance & & $-1.42 \pm 0.14$ & -10.12 \\
\hline & Country:Distance & Spain:Distance & $1.29 \pm 0.17$ & 7.64 \\
\hline \multirow[t]{14}{*}{ Cinereous vulture locations density } & \multirow[t]{2}{*}{ Country } & Portugal (Intercept) & $-1.74 \pm 0.32$ & -5.47 \\
\hline & & Spain & $1.41 \pm 0.25$ & 5.58 \\
\hline & \multirow[t]{9}{*}{ Habitat } & Non-irrigated arable land (Intercept) & $-1.74 \pm 0.32$ & -5.47 \\
\hline & & Permanently irrigated land & $-0.90 \pm 0.68$ & -1.33 \\
\hline & & Olive groves & $-0.18 \pm 0.66$ & -0.27 \\
\hline & & Agro-forestry areas & $0.71 \pm 0.35$ & 2.04 \\
\hline & & Broad-leaved forest & $-0.43 \pm 0.49$ & -0.88 \\
\hline & & Natural grasslands & $0.58 \pm 0.44$ & 1.33 \\
\hline & & Sclerophyllous vegetation & $1.41 \pm 0.45$ & 3.13 \\
\hline & & Transitional woodland-shrub & $0.50 \pm 0.37$ & 1.30 \\
\hline & & Others & $-1.27 \pm 0.66$ & -1.94 \\
\hline & Roughness & & $0.39 \pm 0.09$ & 4.41 \\
\hline & Distance & & $-0.73 \pm 0.18$ & -4.12 \\
\hline & Country:Distance & Spain:dist & $0.73 \pm 0.21$ & 3.51 \\
\hline
\end{tabular}

countries can have far-reaching impacts on biodiversity, thereby calling for better sanitary and environmental policies at the European level.

Although our study has some limitations, it is unlikely that they have shaped our main results and conclusions to a significant extent. One potential problem was that we did not track vultures from Portuguese breeding colonies, which are mainly located close to the border ( $<50 \mathrm{~km}$; Monteiro et al., 2009; Fig. A2) and thus might use the Portuguese territory more than individuals breeding in Spain. However, some limited GPS tracking of cinereous and griffon vultures tagged in Portugal has shown that the individuals tend to cross the border to feed in Spain (Machado, 2014), which is line with the results of our study. Our results are also supported by the fact that the two vulture species are rarely seen in Portugal, except very close to the border with Spain or during the autumn migration period (Catry et al., 2010; Lourenço, 2011). Other possible source of bias is the lack of fine spatial information about the abundance of wild ungulates, which are important providers of carrion in the Iberian Peninsula (Cortés-Avizanda et al., 2016). Nonetheless, the relative homogeneous distribution of the main wild ungulates species throughout the study area (Apollonio et al., 2010) suggests that the availability of wild ungulate carrion is not abruptly different between the Spanish and the Portuguese sides of the study area.

Also, the marked individuals were biased towards adults in the case of griffon vultures and non-adults in the case of cinereous vultures. This could be a problem because immature vultures usually have expanded home ranges due to dispersal movements (e.g., Margalida et al., 2016). However, the movement pattern in relation to the border was consistent for the two species studied. In addition, our set of marked griffon vultures probably included non-breeder individuals, which are free of reproductive duties and could therefore move in a different way than breeders. However, in view of the similar results obtained by the two modelling approaches used in this study (i.e., GLM and GLMM), is evident that our results are not influenced by individual characteristics. All this suggest that the frontier effect produced by the unequal sanitary policies in Spain and Portugal is strong enough to shape vulture movements beyond age class, sex, breeding status and species. That said griffon and cinereous vultures are known to differ in their trophic resource used. In fact, while griffon vultures are strongly dependent on the carcasses of domestic ungulates (Donázar et al., 2010), the diet of cinereous vultures is more varied, including the remains of small and medium-sized vertebrates such as European rabbits Oryctolagus cuniculus (Linnaeus, 1758; European rabbit; Moreno-Opo et al., 2010). This may explain why the density of livestock was included in the model for griffon vultures, but not for cinereous vultures, which was the main difference between the models of both species.

It is also unlikely that the differences between countries observed in our study were due to variation in habitat composition, because the landscapes were rather similar on both sides of the border. We found that both vulture species showed clear preferences for natural and seminatural vegetation, mainly represented by dehesa/montado landscapes that were widespread in both Portugal and Spain. This is in line with other studies showing the importance of dehesas/montados for vultures (Carrete and Donázar, 2005), and for Mediterranean biodiversity in general (Moreno et al., 2016). However, due to the application of restrictive sanitary regulations, Portuguese montados seem to lack a fundamental component of Mediterranean wood-pasturelands, namely livestock carcasses. Given that many endangered species, such as vultures and large predators, rely largely on ungulate carcasses (Pereira et al., 2014; Mateo-Tomás et al., 2015), carrion-free ecosystems such as montados, as currently managed, seem to lack a high value for scavenger conservation.

Reduced foraging opportunities for vultures in Portugal as a result of the restrictive national regulation on livestock carcass disposal could undermine the effectiveness of local conservation strategies (e.g., two LIFE projects devoted to improving the conservation status of Portuguese vulture populations, with an overall budget of $€ 6.2$ million; http://ec.europa.eu/environment/life/project/Projects/). In addition, the large-scale spatial exclusion of keystone species such as vultures 
might ultimately constrain ecosystem functioning and the provision of key ecosystem services (López-Hoffman et al., 2010; Ogada et al., 2012; Moleón et al., 2014). Thus, our findings highlight the need to evaluate the potential ecological consequences of the implementation of restrictive sanitary policies, especially when they affect highly mobile, endangered species such as vultures (Margalida et al., 2010). We advocate for the traditional system of livestock carcass disposal (CortésAvizanda et al., 2010; Arrondo et al., 2015; Cortés-Avizanda et al., 2016), which would benefit European scavenger conservation without compromising animal and human health (Morales-Reyes et al., 2015, 2017). Our results also highlight the role that vultures play as biological indicators of relevant ecological processes at the supra-national scale. Future research including tagging birds of all age classes of these and other vulture species (i.e., Egyptian vulture Neophron percnopterus), as well as the fine quantification of both wild and domestic ungulate carrion biomass availability, may help to go more deeply into the effects of the sanitary policies regarding livestock carcass removal on vulture movements.

Biodiversity management is usually implemented at regional and national scales (Kark et al., 2009). However, the spatiotemporal scale of many ecological processes is independent of national socio-economic contexts, which produces a mismatch between wildlife conservation needs and management units (Dallimer and Strange, 2015). Our study demonstrates how uncoordinated environmental management might become an unexpected limiting factor for species of conservation concern. Even inside a relatively homogeneous political entity such as the European Union, where all members comply with the same directives, national variations in policy implementation may still jeopardize largescale conservation efforts (Gervasi et al., 2015). Thus, trans-boundary biodiversity conservation in Europe would largely benefit from supervision by the EU Commission of local applications of general regulations. In general, more fluid transnational coordination of environmentrelated policies is encouraged, especially for the sake of conserving highly mobile organisms.

\section{Acknowledgements}

This research was funded by the Consejeria de economia innovacion ciencia y empleo Junta de Andalucia (Proyecto de Excelencia 2012 RNM-1925) (Junta de Andalucía), Comunidad de Bardenas Reales de Navarra (Convenios EBD-CSIC 2014-2017), and MInisterio de Economia, Industria y competitividad (Projecto CGL2015-66966-C2-12-R) (Spanish Ministry of Economy and Competitiveness and EU/ FEDER). We thank B.P. for her help with English language. EA was supported by La Caixa-Severo Ochoa International PhD Program 2015, MM by the Severo Ochoa Program for Centres of Excellence in R + D + I (SEV-2012-0262) and by a research contract Ramón y Cajal from the MINECO (RYC-2015-19231), ACA by a post-doctoral contract Juan de la Cierva Incorporación (IJCI-2014-20744) of the Spanish Ministry of Economy and Competitiveness, and PB by EDP Biodiversity Chair.

\section{Appendix A. Supplementary data}

Supplementary data to this article can be found online at https:// doi.org/10.1016/j.biocon.2017.12.039.

\section{References}

Aarts, G., Fieberg, J., Matthiopoulos, J., 2012. Comparative interpretation of count, presence-absence and point methods for species distribution models. Methods Ecol. Evol. 3, 177-187.

Acácio, V., Dias, F.S., Catry, F.X., Rocha, M., Moreira, F., 2016. Landscape dynamics in Mediterranean oak forests under global change: understanding the role of anthropogenic and environmental drivers across forest types. Glob. Chang. Biol. 23, 1199-1217.

AEMET, I, 2011. Atlas climático ibérico/Iberian climate atlas. In: Agencia Estatal de Meteorología, Ministerio de Medio Ambiente y Rural y Marino. Instituto de Meteorologia de Portugal, Madrid.
Apollonio, M., Andersen, R., Putman, R. (Eds.), 2010. European ungulates and their management in the 21st century. Cambridge University Press.

Arrondo, E., Cortés-Avizanda, A., Donázar, J.A., 2015. Temporally unpredictable supplementary feeding may benefit endangered scavengers. Ibis 157, 648-651.

BirdLife International. 2016. Gyps fulvus. The IUCN Red List of Threatened Species 2016: e.T22695219A93497070. https://doi.org/10.2305/IUCN.UK.2016-3.RLTS. T22695219A93497070.en. Downloaded on 28 November 2017.

BirdLife International. 2017. Aegypius monachus. (amended version published in 2016) The IUCN Red List of Threatened Species 2017: e.T22695231A110774064. https:// doi.org/10.2305/IUCN.UK.2017-1.RLTS.T22695231A110774064.en. Downloaded on 28 November 2017.

Bolger, D.T., Newmark, W.D., Morrison, T.A., Doak, D.F., 2008. The need for integrative approaches to understand and conserve migratory ungulates. Ecol. Lett. 11, 63-77.

Carrete, M., Donázar, J.A., 2005. Application of central-place foraging theory shows the importance of Mediterranean dehesas for the conservation of the cinereous vulture, Aegypius monachus. Biol. Conserv. 126, 582-590.

Catry, P., Costa, H., Elias, G., Matias, R., 2010. Aves de Portugal: Ornitologia do território continental. Assirio \& Alwin.

CEC, 2012. CORINE Land Cover, Commission of the European Communities. ECSC-EECEAEC, Brussels, Luxembourg.

Clark Labs, 2000. Global change data archive. In: 1 kem Global Elevation Model. Vol. 3 Clark University.

Cohn, J.P., 2007. The environmental impacts of a border fence. Bioscience 57, 96.

Core Team, R., 2016. R: A language and environment for statistical computing. $\mathrm{R}$ Foundation for Statistical Computing, Vienna, Austria. www.R-project.org/.

Cortés-Avizanda, A., Carrete, M., Donázar, J.A., 2010. Managing supplementary feeding for avian scavengers: guidelines for optimal design using ecological criteria. Biol. Conserv. 143, 1707-1715.

Cortés-Avizanda, A., Blanco, G., DeVault, T.L., Markandya, A., Virani, M.Z., Brandt, J., Donázar, J.A., 2016. Supplementary feeding and endangered avian scavengers: benefits, caveats, and controversies. Front. Ecol. Environ. 14, 191-199.

Dallimer, M., Strange, N., 2015. Why socio-political borders and boundaries matter in conservation. Trends Ecol. Evol. 30, 132-139.

Dilts, T.E., 2015. Topography Tools for ArcGIS 10.1. University of Nevada, Reno.

Donázar, J.A., Margalida, A., Carrete, M., Sánchez-Zapata, J.A., 2009. Too sanitary for vultures. Science 326, 664 .

Donázar, J.A., Cortés-Avizanda, A., Carrete, M., 2010. Dietary Shifts in Two Vultures After the Demise of Supplementary Feeding Stations: Consequences of the EU Sanitary Legislation. Eur. J. Wildl. Res. 56, 613-621.

Dormann, C.F., McPherson, J.M., Araújo, M.B., Bivand, R., Bolliger, J., Carl, G., ... Kühn I, 2007. Methods to account for spatial autocorrelation in the analysis of species distributional data: a review. Ecography 30 (5), 609-628.

ESRI, 2016. ArcGIS Desktop: Release 10.2.1. Environmental Systems Research Institute, Redlands, CA.

García-Matarranz, V., 2011. Red abatible automática para la captura de especies silvestres. ES2009000004320090108.

Garrido, P., Elbakidze, M., Angelstam, P., Plieninger, T., Pulido, F., Moreno, G., 2017. Stakeholder perspectives of wood-pasture ecosystem services: a case study from Iberian dehesas. Land Use Policy 60, 324-333.

Gervasi, V., Brøseth, H., Nilsen, E.B., Ellegren, H., Flagstad, Ø., Linnell, J.D., 2015. Compensatory immigration counteracts contrasting conservation strategies of wolverines (Gulo gulo) within Scandinavia. Biol. Conserv. 191, 632-639.

Hodge, I., Hauck, J., Bonn, A., 2015. The alignment of agricultural and nature conservation policies in the European Union. Conserv. Biol. 29, 996-1005.

ICNB, 2017. Plano nacional para a conservação das aves necrófagas - documento técnico. Relatório não publicado.

Kark, S., Levin, N., Grantham, H.S., Possingham, H.P., 2009. Between-country collaboration and consideration of costs increase conservation planning efficiency in the Mediterranean Basin. Proc. Natl. Acad. Sci. U. S. A. 106, 15368-15373.

Kenward, R.E., 2000. A Manual for Wildlife Radio Tagging. Academic Press.

Kukkala, A.S., Arponen, A., Maiorano, L., Moilanen, A., Thuiller, W., Toivonen, T., Zupan, L., Brotons, L., Cabeza, M., 2016. Matches and mismatches between national and EUwide priorities: examining the Natura 2000 network in vertebrate species conservation. Biol. Conserv. 198, 193-201.

Lambertucci, S.A., Alarcón, P.A.E., Hiraldo, F., Sanchez-Zapata, J.A., Blanco, G., Donázar, J.A., 2014. Apex scavenger movements call for transboundary conservation policies. Biol. Conserv. 170, 145-150.

Lasky, J.R., Jetz, W., Keitt, T.H., 2011. Conservation biogeography of the US-Mexico border: a transcontinental risk assessment of barriers to animal dispersal. Divers. Distrib. 17, 673-687.

López-Hoffman, L., Varady, R.G., Flessa, K.W., Balvanera, P., 2010. Ecosystem services across borders: a framework for transboundary conservation policy. Front. Ecol. Environ. 8, 84-91.

Lourenço, P.M., 2011. Unravelling the occurrence patterns of cinereous vultures Aegypius monachus in southern Portugal using non-standardized observations. Airo 23, 15-23.

Machado, C., 2014. Innovative actions against illegal poisoning in European Mediterranean pilot areas. Layman's Report of Project LIFE 09/NAT/ES/000533. Fundación Gypaetus, Jaén. Available from: http://www.gypaetus.org/EN_IAP_ Laymans\%20Report_low.pdf, Accessed date: 9 May 2017.

MAPAMA, 2017. Ministerio de Agricultura y Pesca. Alimentación y Medio Ambiente. http://www.mapama.gob.es/es/biodiversidad/temas/inventarios-nacionales/ inventario-especies-terrestres/.

Margalida, A., Donázar, J.A., Carrete, M., Sánchez-Zapata, J.A., 2010. Sanitary versus environmental policies: fitting together two pieces of the puzzle of European vulture conservation. J. Appl. Ecol. 47, 931-935.

Margalida, A., Colomer, M.À., Sanuy, D., 2011. Can wild ungulate carcasses provide 
enough biomass to maintain avian scavenger populations? An empirical assessment using a bio-inspired computational model. PLoS One 6, e20248.

Margalida, A., Carrete, M., Sánchez-Zapata, J.A., Donázar, J.A., 2012. Good news for European vultures. Science 335, 284.

Margalida, A., Pérez-García, J.M., Afonso, I., Moreno-Opo, R., 2016. Spatial and temporal movements in Pyrenean bearded vultures (Gypaetus barbatus): integrating movement ecology into conservation practice. Sci. Rep. 6.

Mateo-Tomás, P., Olea, P.P., Moleón, M., Vicente, J., Selva, N., Botella, F., ... Sánchez-Zapata, J.A., 2015. From regional to global patterns in vertebrate scavenger communities subsidized by big game hunting. Divers. Distrib. 21 (8), 913-924.

Moleón, M., Sánchez-Zapata, J.A., Margalida, A., Carrete, M., Donázar, J.A., Owen-Smith, N., 2014. Humans and scavengers: the evolution of interactions and ecosystem services. Bioscience 64, 394-403.

Monteiro, A., Pacheco, C., Santos, N., 2009. Population trends, distribution, and conservation concerns of vultures in Portugal. In: Donázar, J.A., Margalida, A., Campión, C. (Eds.), Vultures, Feeding Stations and Sanitary Legislation: A Conflict and its Consequences From the Perspective of Conservation Biology. Munibe, San Sebastián, pp. 200-223.

del Moral, J.C. (Ed.), 2009. El buitre leonado en España. Población reproductora en 2008 y método de censo. SEO/BirdLife, Madrid.

Morales-Reyes, Z., Pérez-García, J.M., Moleón, M., Botella, F., Carrete, M., Lazcano, C., Sánchez-Zapata, J.A., 2015. Supplanting ecosystem services provided by scavengers raises greenhouse gas emissions. Sci. Rep. 5, 7811.

Morales-Reyes, Z., Pérez-García, J.M., Moleón, M., Botella, F., Carrete, M., Donázar, J.A., Cortés-Avizanda, A., Arrondo, E., Moreno-Opo, R., Margalida, A., 2017. Evaluation of the network of protection areas for the feeding of scavengers in Spain: from biodiversity conservation to greenhouse gas emission savings. J. Appl. Ecol. 54 $1120-1129$.

Moreno, G., Gonzalez-Bornay, G., Pulido, F., Lopez-Diaz, M.L., Bertomeu, M., Juárez, E., Diaz, M., 2016. Exploring the causes of high biodiversity of Iberian dehesas: the importance of wood pastures and marginal habitats. Agrofor. Syst. 90, 87-105.

Moreno-Opo, R., Margalida, A., Arredondo, A., Guil, F., Martín, M., Higuero, R., Guzman, J., 2010. Factors influencing the presence of the cinereous vulture Aegypius monachus at carcasses: food preferences and implications for the management of supplementary feeding sites. Wildl. Biol. 16, 25-34.

Ogada, D.L., Keesing, F., Virani, M.Z., 2012. Dropping dead: causes and consequences of vulture population declines worldwide. Ann. N. Y. Acad. Sci. 1249, 57-71.

Pereira, L.M., Owen-Smith, N., Moleon, M., 2014. Facultative predation and scavenging by mammalian carnivores: seasonal, regional and intra-guild comparisons. Mammal Rev. 44, 44-55.

Perz, S.G., Qiu, Y., Xia, Y., Southworth, J., Sun, J., Marsik, M., Barnes, G., 2013. Transboundary infrastructure and land cover change: highway paving and communitylevel deforestation in a tri-national frontier in the Amazon. Land Use Policy 34, 27-41.

de la Puente, J., Moreno-Opo, R., del Moral, J.C., 2007. El buitre negro en España. Censo Nacional 2006. SEO/BirdLife, Madrid.

Sales-Baptista, E., d'Abreu, M.C., Ferraz-de-Oliveira, M.I., 2016. Overgrazing in the Montado? The need for monitoring grazing pressure at paddock scale. Agrofor. Syst. 90, 57-68.

Sánchez-Fernández, D., Abellán, P., Aragón, P., Varela, S., Cabeza, M., 2017. Matches and mismatches between conservation investments and biodiversity values in the European Union. Conserv. Biol. http://dx.doi.org/10.1111/cobi.12977.

Sandwith, T., Shine, C., Hamilton, L., Sheppard, D., 2001. Protected Areas for Peace and Co-operation (No. 7). Best Practice Protected Area Guidelines Series.

SAS Institute, 2009. SAS/STAT 9.2. Language Reference: Concepts. SAS Institute, Cary, North Carolina, USA.

Silva, R., Afán, I., Gil, J.A., Bustamante, J., 2017. Seasonal and circadian biases in bird tracking with solar GPS-tags. PLoS One 12, e0185344.

Wolmer, W., 2003. Transboundary conservation: the politics of ecological integrity in the Great Limpopo Transfrontier Park. J. South. Afr. Stud. 29, 261-278. 